adenopathy in this woman with Felty's syndrome resulted in an initial diagnosis of carcinoma. Awareness of this rare presentation may aid earlier diagnosis and prevent undue treatment for carcinoma.

We thank Mrs S M Walker for allowing us to report this case.

1 Bullough PG. Rheumatoid arthritis. In: Sternberg SS, ed. Diagnostic surgical pathology. 2nd edn. New York: Raven Press, 1994:235-6.

2 Patterson JW, Demos PT. Superficial ulcerating rheumatoid necrobiosis: a perforating rheumatoid nodule. Cutis 1985 ; 36:323-8.
3 Horn RT, Goette DK. Perforating rheumatoid nodule. Arch Dermatol 1982;118:696-7.

Ziff M. The rheumatoid nodule. Arthritis Rheum 1990;33: 761-7.

5 Sokoloff L, McCluskey RT, Bunim JJ. Vascularity of the early subcutaneous nodule of rheumatoid arthritis. Arch Pathol subcutaneous nodu

6 Roberts JT, Roberts GT, Maudsley RF. Indolent granulomatous necrosis in patients with previous tubal diathermy Am $\mathcal{F}$ Obstet Gynecol 1977;129:112-13.

7 Akosa AB, Boret F. Necrotising granulomas of the uterine corpus. $\mathcal{F}$ Clin Pathol 1993;46:953-5.

8 Evans CS, Klein HZ, Goldman RL, Kohout ND. Necrobiotic granulomas of the uterine cervix. Am $\mathcal{F}$ Surg Pathol 1984; 8:841-4.

9 Herbold DR, Frable WJ, Kraus FT. Isolated noninfectious granulomas of the ovary. Int $\mathcal{f}$ Gynecol Pathol 1984;2: 380-91.

\title{
Pleomorphic adenoma of the bronchus
}

\author{
E C Sweeney, M McDermott
}

\begin{abstract}
An example of pleomorphic adenoma of the bronchus is described in a 27 year old male student who was referred for evaluation of a coin lesion identified incidentally on chest $x$ ray. The tumour exhibited the classic histological, immunohistochemical and ultrastructural features of this rare entity but, in addition, contained mature and immature adipose tissue in the stroma and showed transition, in its superficial portion, between ostensibly normal bronchial mucus glands and tumour tubules. Neither of these features has been commented upon previously. (f Clin Pathol 1996;49:87-89)
\end{abstract}

Keywords: bronchus, pleomorphic adenoma, adipose tissue, mucus glands.

\section{Case report}

A 27 year old male student was referred for evaluation of a coin lesion identified incidentally on chest $x$ ray. An $x$ ray taken four years earlier for an insurance examination had been reported as normal. The patient had no symptoms and no past medical history. He had smoked 20 cigarettes daily up to four months before presentation. Physical examination and routine laboratory tests were normal.

Computed tomography examination revealed a $3 \mathrm{~cm}$ enhancing mass, with well defined margins, at the hilum of the right lung. On endoscopy, a polypoid tumour was seen in the lower lobe bronchus, but biopsy specimens of the surface of this were not diagnostic. A lower lobectomy was performed. On gross examination, there was a well circumscribed $3.5 \mathrm{~cm}$ grey-yellow tumour, largely located within pulmonary parenchyma but projecting intraluminally through the wall of the bronchus, $2 \mathrm{~cm}$ from the bronchial resection margin.

\section{Methods}

Tissue blocks were fixed in $10 \%$ buffered formalin, routinely processed and embedded in paraffin wax. Sections were stained with haematoxylin and eosin, alcian blue $(\mathrm{pH} 2.5)$ and periodic acid Schiff (PAS) after diastase pretreatment. Sequential sections were stained for keratin (AE1/AE3; ICN, Costa Mesa, California, USA), S100 protein and epithelial membrane antigen (EMA) (Dako, Glostrup, Denmark) and smooth muscle actin (Enzo Diagnostics, New York, USA). Further tissue blocks were fixed in 3\% glutaraldehyde and examined by electron microscopy.

\section{MICROSCOPY}

On its bronchial aspect, the lesion was covered by normal respiratory epithelium. Within the lung, however, it was separated from normal parenchyma by a dense fibrous capsule of variable thickness. Peribronchial adipose tissue was present at the resection margin of the lobectomy specimen but not in the immediate vicinity of the tumour. The mass was roughly spherical and, at its centre, had a stellate, parvicellular area, radiating from which were irregular, solid islands of polygonal epithelial cells with moderate amounts of eosinophilic cytoplasm, and scattered cells, either singly or in groups, in which the cytoplasm had a more hyaline, glassy appearance. The stroma between the cellular areas contained spindle shaped and stellate cells set in a variably myxoid, hyaline or focally chondroid matrix. Zones of adipose tissue were easily identifiable in the stroma (figure, panel A), some of which contained lipoblasts (figure, panel B). In both the cellular and myxoid areas there were well formed tubular structures, many of which were lined by distinct epithelial and myoepithelial layers. Squamous metaplasia was identified in 


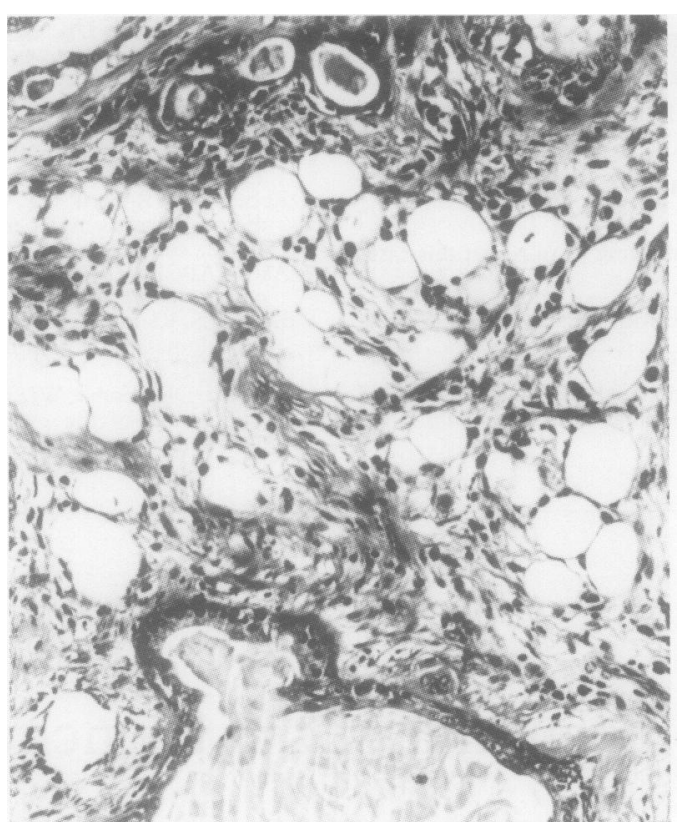

(A)

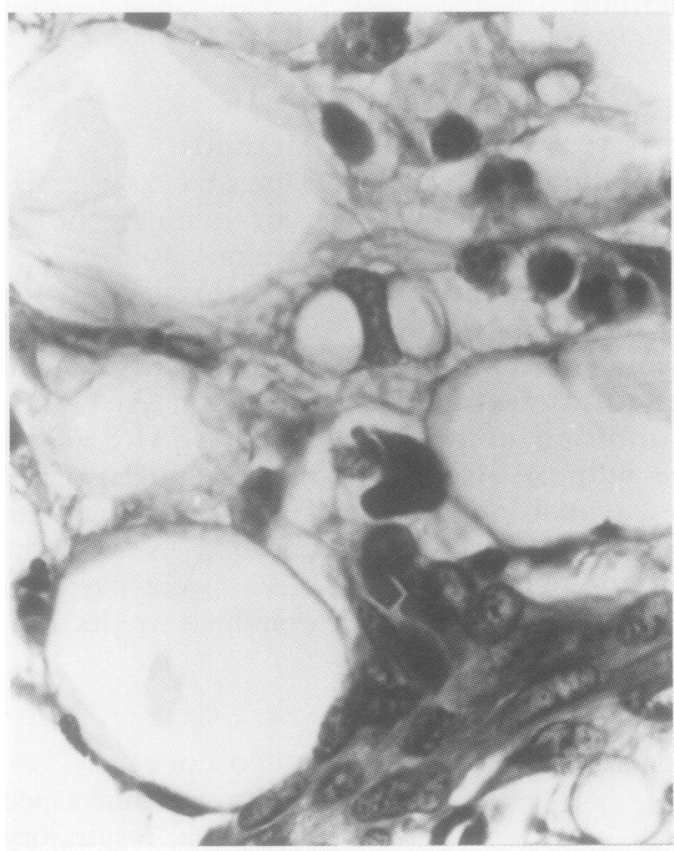

(B)

(A) Area of adipose tissue in the tumour stroma.

(B) $A$ lipoblast (centre) is visible amidst a group of more mature appearing adipocytes.

a few of these tubular structures, particularly in the deeper intrapulmonary areas of the tumour. No foci of necrosis were seen and mitoses were very rare.

Of interest were those glandular spaces which were lined by mucin containing cells similar to those lining ostensibly normal bronchial mucus glands of the overlying mucosa. Such glands were only identified close to the intrabronchial portion of the tumour, were often cystically dilatated and, in places, merged imperceptibly with tumour tubules lined by cells with very little, or no, intracytoplasmic mucin.

Histochemical stains (PAS/diastase and alcian blue) confirmed the presence of large quantities of both neutral and acid mucins in the tumour stroma, in tubular lumina and in the mucus cells of the superficial zone of the tumour.

The cells lining the tubules and most of the solid epithelial islands stained positively for keratin, whereas only the luminal aspect of these cells stained with antibody to EMA. S100 protein and smooth muscle actin were demonstrable in myoepithelial cells around tubules and also in single cells, or groups of cells, in solid epithelial zones, corresponding to the cells with hyaline cytoplasm noted on staining with haematoxylin and eosin. The peritubular distribution of myoepithelial cells was very variable, ranging from scattered peripheral cells in those glands with mucin secreting epithelium to continuous runs of such cells enclosing classic tumour tubules. Other tubules showed completely haphazard distribution of myoepithelial cells, in solid clumps or even lying inside the epithelial cell layer. Adipocytes stained strongly for $S 100$ protein but not for actin or EMA.

\section{ELECTRON MICROSCOPY}

Epithelial cells lining tubules varied from cuboidal to columnar, the former often containing little mucin and the latter numerous mucin vacuoles. Both of these cell types demonstrated poorly formed, stubby microvilli on the luminal surface. Tight junctions were evident at the luminal aspects of epithelial cells and, elsewhere, desmosomes were plentiful between epithelial and myoepithelial cells. These latter cells, with cytoplasmic aggregates of thin filaments and overlapping dense bodies, were not only related to tubular structures but were also present isolated in the myxoid stroma. Flattened epithelial cells containing bundles of tonofilaments were readily identified. Adipocytes were ultrastructurally unremarkable and, in particular, myofilaments were not identified in the cytoplasm, nor were such filaments observed in cells which had the morphology of lipoblasts (figure, panel B).

\section{Discussion}

Pleomorphic adenoma of the bronchus is extremely uncommon, with approximately 20 verifiable cases documented to date. ${ }^{1}$ At 27 years of age, the case presented here is the youngest on record, previous cases falling within the age range of 35-74 years. About one third of all cases come to light incidentally, as in the case reported here.

The histological and ultrastructural features of pleomorphic adenoma of the bronchus, as seen in this case, are identical with those of lesions arising in salivary gland. ${ }^{2}$ Features, however, which have not been annotated previously, include the presence of adipose tissue within the stroma and the apparent continuity of the tumour tubules with glandular structures which resemble normal mucus glands, towards the bronchial luminal surface. This latter phenomenon is consonant with the hypothesis that pleomorphic adenoma arises from cells of the intercalated duct ${ }^{3}$ but we have been unable to find reference to this spatial juxtaposition in other reports of this condition. 
Adipose tissue in salivary pleomorphic adenomas is well recognised ${ }^{4}$ although its derivation remains unclear. There are three possible explanations for its presence: first, that it is the result of the incorporation of preexisting stromal fat of the organ in which the tumour has arisen; second, that it represents adipose differentiation of mesenchymal cells in a true biphasic tumour; or, third, that it is caused by adipose metaplasia of primordial myoepithelial cells. While the first possibility might be invoked for pleomorphic adenomas arising in fatty organs such as breast, salivary gland or skin, it seems less likely in the context of the lung where fat is, at best, sparse and which, in this case, was not evident immediately adjacent to the tumour. If one believes, as the weight of evidence tends to suggest, that pleomorphic adenoma "is not a true mixed tumour but is of solely epithelial origin, and that the connective tissue appearances are secondary" then the second postulate seems unsafe. If, as we believe, the third suggestion is true (and the presence of cells (figure, panel B) with the morphological characteristics of lipoblasts ${ }^{6}$ argues that this might be so, absence of myofilaments on electron microscopy notwithstanding) then adipose metaplasia might be added to the list of morphologies ${ }^{3}$ that modified myoepithelial cells can adopt.

Because so few cases of pleomorphic adenoma of the bronchus have been documented it is difficult to assess their prognosis. Undoubted malignant variants have been described ${ }^{178}$ which, in addition to the generally accepted histological features of malignancy, such as necrosis and high mitotic rate, tend to be larger than their benign counterparts. ${ }^{1}$

In the salivary gland pleomorphic adenomas are notorious for their tendency to recur, principally because of their gross morphology and the difficulty in achieving adequate excision in surgically complicated terrain. ${ }^{2}$ Genuine recurrence of a benign pleomorphic adenoma of the bronchus, however, has been recorded only once $^{9}$ and in that instance it is unclear if adequate resection of the primary tumour was achieved. The "recurrence" documented by Sakamoto et $a l^{10}$ is difficult to accept as such, principally because it was found in the periphery of the opposite lung, nine years after initial lobectomy. The possibility that this predominantly chondroid tumour might have represented asynchronous metastases from an undetected low grade mesenchymal tumour elsewhere was not entertained.

It would appear logical, therefore, that benign pleomorphic adenomas of the bronchus should not recur if, as in this case, an adequate resection margin can be obtained.

Our thanks to Mr David Luke for clinical information, to Jan Walker for photographic assistance and to Carol McCormick and Anne Mynes for electron microscopy.

1 Moran CA, Suster S, Askin FB, Koss MN. Benign and malignant salivary gland-type mixed tumors of the lung: clinicopathologic and immunohistochemical study of eigh cases. Cancer 1994;73:2481-90.

2 Huvos AG. Salivary glands. In: Sternberg SS, ed. Diagnostic surgical pathology. 2nd edn. New York: Raven Press, 1994: 813-17.

3 Martinez-Madrigal F, Micheau C. Major salivary glands. In: Sternberg SS, ed. Histology for pathologists. New York: Raven Press, 1992:468.

4 Thackray AC, Lucas RB. Tumors of the major salivary glands. In: Atlas of tumor pathology. 2nd series. Fascicle 10. Washington DC: AFIP, 1974 .

5 Speight PM, Tinkler S. The salivary glands. In: McGee JO'D, Isaacson PG, Wright NA, eds. Oxford textbook of pathology. Vol 2(a). Oxford: Oxford University Press, 1992 1075

6 Brooks JJ, Perosio PM. Adipose tissue. In: Sternberg SS, ed. Histology for pathologists. New York: Raven Press, 1992: 56.

7 Spencer H. Bronchial mucous gland tumours. Virchows Arch A Pathol Anat Histopathol 1979;38:101-15.

8 Hayes M, van der Westhuizen N, Forgie R. Malignant mixed tumour of the bronchus: A biphasic neoplasm of epithelial tumour of the bronchus: A biphasic neoplasm of ep

9 Payne W, Schier J, Woolner I. Mixed tumours of the bronchus, salivary gland type. F Thorac Cardiovasc Surg bronchus, salivary

10 Sakamoto H, Uda H, Tanaka T, Oda T, Morino H, Kikui $M$. Pleomorphic adenoma in the periphery of the lung: Report of a case and review of the literature. Arch Pathol Lab Med 1991;115:393-6.
Laboratoire de

Biochimie, Hôpital

Louis-Mourier,

Colombes, France

$\mathrm{J}$ Lamoril

J-C Deybach

Hôpital Saint-Louis, Paris, France: Clinique des Maladies

Infectieuses et

Tropicales

J-M Molina

A de Gouvello

J Modaï

Laboratoire de ParasitologieMycologie

Y J Garin

F Derouin

Correspondence to: Pr F Derouin, Laboratoire de Parasitologie-Mycologie, Hôpital Saint-Louis, 1 avenue Claude Vellefaux, 75010 Paris, France.

75010 Paris, France. 20 July 1995

\section{Detection by PCR of Toxoplasma gondii in blood in the diagnosis of cerebral toxoplasmosis in patients with AIDS}

\author{
J Lamoril, J-M Molina, A de Gouvello, Y J Garin, J-C Deybach, J Modaï, F Derouin
}

\begin{abstract}
The polymerase chain reaction (PCR) for amplification of Toxoplasma gondii DNA was performed prospectively in the blood of 19 patients with AIDS and cerebral toxoplasmosis. The B1 gene and TGR1E sequence were used as targets and results were confirmed by hybridisation. Controls consisted of $24 \mathrm{HIV}$ infected patients with tissue culture proven $T$ gondii para-
\end{abstract}

sitaemia and 57 HIV infected patients without toxoplasmosis. PCR was positive with both targets in 20 of 24 samples (84\%) from patients with parasitaemia. Three of 57 samples (5\%) from patients without toxoplasmosis were PCR positive with either target, but none was positive with both targets. Only three of the 19 patients (16\%) with cerebral toxoplasmosis had a positive PCR with both targets before the 